\title{
Loss of Negative Feedback Control of Nuclear Factor- $\kappa$ B2 Activity in Lymphocytes Leads to Fatal Lung Inflammation
}

\author{
Liqun Yang, ${ }^{\text {† }}$ Hongjuan Cui, ${ }^{* \ddagger}$ Zhe Wang, ${ }^{\text {* }}$ \\ Baochun Zhang, ${ }^{*}$ Jane Ding, ${ }^{\dagger}$ Lin Liu, ${ }^{\S}$ \\ and Han-Fei Ding ${ }^{\dagger}$ \\ From the Department of Biochemistry and Cancer Biology,* \\ University of Toledo Health Science Campus, Toledo, Obio; \\ the Cancer Center and the Department of Pathology, ${ }^{\dagger}$ Medical \\ College of Georgia, Augusta, Georgia; The Key Sericultural \\ Laboratory of Agricultural Ministry, ${ }^{\ddagger}$ Southwest University, \\ Chongqing, China; and the Department of Pathology, Evanston \\ Hospital, Evanston, Illinois
}

Proteolytic processing of the nuclear factor (NF)- $\kappa \mathrm{B} 2$ precursor protein $\mathbf{p 1 0 0}$ generates the active NF- $\kappa \mathrm{B} 2$ subunit $\mathbf{p 5 2}$, which in turn transcriptionally up-regulates p100 expression. p100 also functions as an IKB molecule capable of repressing $\mathrm{p} 52$ activity. The biological significance of this negative feedback control loop has yet to be demonstrated in vivo. Here we show that mice deficient in $\mathbf{p 1 0 0}$ but with constitutive expression of $\mathbf{p 5 2}$ in lymphocytes developed fatal lung inflammation characterized by diffuse alveolar damage with marked peribronchial fibrosis. In contrast, their littermates with only p100 deficiency or constitutive expression of $\mathbf{p} 52$ in lymphocytes developed mild lung inflammation with perivascular lymphocyte infiltration and had a normal life span. The fatal lung inflammation is associated with high-level induction of interferon- $\gamma$ and its inducible inflammatory chemokines, suggesting the involvement of a T-helper-1 immune response. These findings demonstrate the physiological relevance of the NF- $\mathrm{KB} 2 \mathrm{p} 100$ precursor protein in limiting the potentially detrimental effects of constitutive NF- $\kappa$ B2 signaling in lymphocytes. (Am J Pathol 2010, 176:2646-2657; DOI: 10.2353/ajpath.2010.090751)

Nuclear factor (NF)- $\kappa$ B2 is a member of the NF- $\kappa$ B family of transcription factors that also include NF- $\kappa$ B1 (p105/ p50), RelA (p65), RelB, and c-Rel. It is synthesized as a large precursor of 100-kDa protein (p100) and processed by the proteasome to generate p52, corresponding to the amino-terminal half of $\mathrm{p} 100$. The activation process is initiated by engagement of the receptors for B-cell-activating factor, ${ }^{1,2}$ lymphotoxin- $\beta,{ }^{3}$ CD40 ligand, ${ }^{4}$ and receptor activator of NF- $\kappa \mathrm{B}$ ligand. ${ }^{5}$ The engagement activates a kinase cascade: NF- $\kappa \mathrm{B}$-inducing kinase activates inhibitor of NF- $\kappa \mathrm{B}\left(\left.\right|_{\kappa} \mathrm{B}\right)$ kinase $\alpha$, which in turn phosphorylates specific serine residues in the carboxyl-terminal region of $\mathrm{p} 100$, targeting it for ubiquitination and partial proteasomal degradation. ${ }^{6,7}$ p52 can form heterodimers with RelB or other Rel proteins. These dimers, once in the nucleus, bind a DNA sequence motif known as the $\kappa B$ site and regulate the expression of genes crucial to the development and functions of lymphocytes. ${ }^{8-10}$

The carboxyl-terminal region of p100 contains seven $l_{\kappa} \mathrm{B}$-like ankyrin repeats with the capacity to retain NF- $\kappa \mathrm{B}$ dimers and Rel proteins in the cytoplasm, including RelB, RelA, c-Rel, and p50, 4,11,12 as well as p50-RelA and p50-RelB dimers. ${ }^{13,14}$ The physiological significance of p100 $\mid \kappa B$ activity is not well understood. In an early effort to address this question, Ishikawa et $\mathrm{al}^{15}$ generated the mutant mice $N F-\kappa B 2^{\Delta c / \Delta c}$ that lack p100 but still express p52. These mice display a marked increase in the nuclear $\kappa$ B-binding activity of p52-containing complexes, enhanced lymphocyte proliferation and cytokine production, enlarged lymph nodes, and severe gastric hyperplasia responsible for their early postnatal death. However, the constitutive production of p52 in the absence of p100 in these mice raises the question of whether the observed phenotype results from lack of p100, overproduction of p52, or both. ${ }^{8}$ In addition, it has been shown that the promoter region of $N F-\kappa B 2$ contains several $\kappa \mathrm{B}$ binding sites, which can be activated by the p52-RelA

Supported by the National Institutes of Health (grant CA106550 to H.-F.D.). H.-F.D. is a Georgia Cancer Coalition Distinguished Scholar.

Accepted for publication February 16, 2010

Current address of H.C.: Department of Stem Cell Biology and Regenerative Medicine, Cleveland Clinic, Cleveland, Ohio; of Z.W.: Department of Medical Oncology, Dana-Farber Cancer Institute, Boston, Massachusetts; of B.Z.: Immune Disease Institute, Harvard Medical School, Boston, Massachusetts.

Address reprint requests to Han-Fei Ding, Ph.D., Cancer Center and Department of Pathology, Medical College of Georgia, 1120 15th St., CN-4132, Augusta, GA 30912. E-mail: hding@mcg.edu. 
dimer as demonstrated in reporter assays, ${ }^{16,17}$ suggesting that p52 could up-regulate the expression of its precursor p100. The biological consequence of this autoregulatory loop has not been established.

To address these questions, we generated lymphocyte-specific p52 transgenic (p52-Tg) mice with or without the NF- $\kappa$ B2 p100 precursor protein. In contrast to their $\mathrm{p} 100^{-1-}$ or $\mathrm{p} 52-\mathrm{Tg}$ littermates, a majority of p52-Tg/ $\mathrm{p} 100^{-1-}$ mice developed fatal lung inflammation characterized by diffuse alveolar damage and high-level induction of the T-helper-1 $\left(T_{H} 1\right)$ signature cytokine interferon (IFN)- $\boldsymbol{\gamma}$ and IFN- $\boldsymbol{\gamma}$-inducible inflammatory chemokines. These findings provide direct evidence for a physiological function of $\mathrm{p} 100$ serving as a surveillance mechanism against aberrant activation of its own signaling pathway.

\section{Materials and Methods}

\section{Mice}

p52-Tg mice (p52 $2^{+-}$, heterozygote) carry a human p52 transgene under the control of an $\mathrm{H}-2 \mathrm{~K}^{\mathrm{b}}$ promoter and an immunoglobulin $\mu$ chain enhancer (pHSE3' expression vector), ${ }^{18}$ which direct the transgene expression specifically in $\mathrm{T}$ and $\mathrm{B}$ lymphocytes. ${ }^{18,19}$ The p52-Tg mice were originally generated on a mixed C57BL/6 $\times$ SJL genetic background $^{18}$ and were subsequently backcrossed with C57BL/6 mice (The Jackson Laboratory, Bar Harbor, ME) for 10 generations. $\mathrm{p} 100^{+/-}$mice ${ }^{20}$ were generated and maintained on the $\mathrm{C} 57 \mathrm{BL} / 6$ genetic background. For this study, $\mathrm{p} 100^{+/-}$and $\mathrm{p} 52^{+/-}$mice (C57BL/6) were first crossed with SJL mice (The Jackson Laboratory) to generate $\mathrm{p} 100^{+/-}$and $\mathrm{p} 52^{+/-}$mice (F1) with the mixed $\mathrm{C} 57 \mathrm{BL} / 6 \times \mathrm{SJL}$ genetic background. The resulting F1 $\mathrm{p} 100^{+/-}$and $\mathrm{p} 52^{+/-}$mice were then interbred to obtain $\mathrm{p} 52^{+/-} / \mathrm{p} 100^{+/-}$and $\mathrm{p} 100^{+/-}$mice (F2). Finally, F2 $\mathrm{p} 52^{+/-} / \mathrm{p} 100^{+/-}$and $\mathrm{p} 100^{+/-}$mice were interbred to generate $\mathrm{p} 52^{+/-}$(p52-Tg), p52-Tg/p100 ${ }^{-1-}, \mathrm{p} 100^{-1-}$, and wild-type mice (F3). Mice of the F3 generation were used in this study and were maintained under specific pathogen-free conditions at the animal facilities of the University of Toledo Health Science Campus and the Medical College of Georgia. Mice were euthanized when they became moribund and then were autopsied. All animal experiments were performed with age-matched littermates and were pre-approved by the Institutional Animal Care and Use Committees of both institutions.

\section{Immunoblotting}

Human fibrosarcoma HT1080 cells overexpressing NF$\kappa \mathrm{B} 2 \mathrm{p} 100, \mathrm{p} 52$, or green fluorescent protein (control) were generated by retroviral infection using pBabe-puro/ p100, pBabe-puro/p52, or pBabe-GFP. ${ }^{21}$ The HT1080 cells and single-cell suspensions of splenocytes from 8-week-old p52-Tg and wild-type mice were directly suspended in SDS sample buffer. Whole-cell extracts were prepared as described previously. ${ }^{22}$ In brief, thymocytes from 4-week-old wild-type, p52-Tg, p52-Tg/p100-1-, and

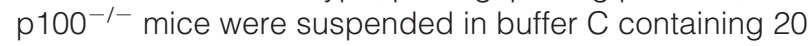

mmol/L HEPES (pH 7.4), 25\% glycerol, 420 mmol/L NaCl, $1.5 \mathrm{mmol} / \mathrm{L} \mathrm{MgCl}_{2}, 0.2 \mathrm{mmol} / \mathrm{L}$ EDTA, and $0.5 \mathrm{mmol} / \mathrm{L}$ phenylmethylsulfonyl fluoride. After three freeze-thaw cycles, insoluble materials were removed by a 10-minute spin in a microcentrifuge at $4^{\circ} \mathrm{C}$, and the supernatants were collected for immunoblot analysis. Proteins $(50 \mu \mathrm{g})$ were separated on 10\% SDS-polyacrylamide gels, transferred to nitrocellulose membranes, probed with antibodies, and visualized by chemiluminescence. The following antibodies were used: rabbit anti-NF- $\kappa$ B2 (no. 4882, 1:500, Cell Signaling Technology, Danvers, MA), rabbit anti-NF- $\mathrm{B} 2$ (no. 06-413, 1:1000, Upstate Biotechnology, Charlottesville, VA), rabbit anti-NF- $\kappa$ B1 p50 (sc-7178, $1: 200)$, rabbit anti-RelA (sc-109x, 1:2000), rabbit antiRelB (sc-226, 1:200), rabbit anti-c-Rel (sc-71x, 1:1000), rabbit anti-Sp1 (sc-59, 1:100), rabbit anti- $\beta$-actin (600401-886, 1:2000, Rockland, Rockland, ME), and mouse anti- $\alpha$-tubulin (B-5-1-2, 1:2000, Sigma-Aldrich, St. Louis, $\mathrm{MO})$. Unless indicated, all antibodies were purchased from Santa Cruz Biotechnology, Inc. (Santa Cruz, CA). Horseradish peroxidase-conjugated anti-mouse and antirabbit antibodies were used as secondary antibodies.

\section{Electrophoretic Mobility Shift Assay}

Nuclear extracts were prepared from 4-week-old mouse thymocytes using a NE-PER nuclear extraction kit (Pierce Chemical, Rockford, IL) and analyzed for $\kappa$ B-binding activity as described previously. ${ }^{21}$ For supershifting, $3 \mu \mathrm{g}$ of extracts were incubated with $2 \mu l$ of either preimmune rabbit serum or rabbit antiserum against NF- $\kappa$ B2 (06-413; Upstate Biotechnology) for 30 minutes at $4^{\circ} \mathrm{C}$ before addition of the ${ }^{32}$ P-labeled $\kappa$ B probe 5'-CAGGGCTGGGGATTCCCCATCTCCACAGTTTCACTTC-3'. 23

\section{Flow Cytometry}

Single-cell suspensions were prepared from mouse lymphoid organs according to standard procedures. ${ }^{24}$ Red

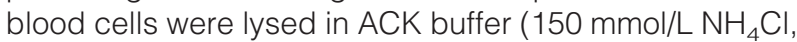

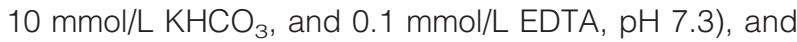
dead cells were removed by passing through Lympholyte-M (Cedarlane, Burlington, NC). Lung-infiltrating cells were isolated as described previously. ${ }^{25}$ The cells were stained with fluorescein isothiocyanate-conjugated rat anti-mouse B220 (RA3-6B2), CD4 (GK1.5), and CD44 (IM7), hamster anti-mouse CD69 (H1.2F3), allophycocyanin-conjugated hamster anti-mouse CD3e (145-2C11), and phycoerythrin-conjugated rat anti-mouse CD4 (RM4-5), CD8a (53-6.7), IgM (R6-60.2), and F4/80 (12-4801, eBioscience, San Diego, CA). Unless indicated, all antibodies were purchased from BD Pharmingen (San Diego, CA). The cells were then sorted on an Epics Elite flow cytometer (Beckman Coulter, Fullerton, CA), and the data were analyzed with WinMDI 2.8 software.

\section{Histopathology and Immunohistochemistry}

Mouse tissues were fixed in 10\% neutral buffered formalin, embedded in paraffin, sectioned at $5 \mu \mathrm{m}$, and stained 
with H\&E or Masson's trichrome. For immunohistochemical staining, the sections were deparaffinized, rehydrated, and treated with $10 \mathrm{mmol} / \mathrm{L}$ citrate buffer $(\mathrm{pH}$ 6.0) or $1 \mathrm{mmol} / \mathrm{L}$ EDTA $(\mathrm{pH} 8.0)$ at $95^{\circ} \mathrm{C}$ for 25 minutes to retrieval antigens. After quenching of endogenous peroxidase activity with $3 \% \mathrm{H}_{2} \mathrm{O}_{2}$ and blocking with normal serum, the sections were incubated with primary antibodies overnight at $4^{\circ} \mathrm{C}$. The following antibodies were used: rat anti-mouse B220 (RA3-6B2, $5 \mu \mathrm{g} / \mathrm{ml}$, BD Pharmingen), rat anti-mouse CCL2 (14-7996, $5 \mu \mathrm{g} / \mathrm{ml}$, eBioscience), rat anti-mouse CCL5 (14-7993, $5 \mu \mathrm{g} / \mathrm{ml}$, eBioscience), rat anti-human/mouse CD3 (MCA 1477, $10 \mu \mathrm{g} /$ $\mathrm{ml}$, Serotec, Oxford, UK), rat anti-mouse F4/80 (Cl:A3-1, $10 \mu \mathrm{g} / \mathrm{ml}$, Serotec), goat anti-mouse CXCL9 (AF-492-NA, $10 \mu \mathrm{g} / \mathrm{ml}$, R\&D Systems, Minneapolis, MN), rabbit antihuman/mouse S100A4 (A5114, $1.25 \mu \mathrm{g} / \mathrm{ml}$, Dako, Carpinteria, CA), mouse anti-mouse $\alpha \mathrm{SMA}$ (1E12 hybridoma supernatant, 1:1 dilution). After washing, a biotinylated secondary antibody (Vector Laboratories, Burlingame, CA) was applied for 30 minutes. The sections were then incubated for 30 minutes with an ABC Elite kit (Vector Laboratories), and immunostaining was visualized with 3,3-diaminobenzidine (Sigma-Aldrich). The sections were counterstained with hematoxylin.

\section{Real-Time PCR}

Total RNA was extracted from mouse lung tissues ( $n=3$ for each genotype, 4-month-old) or lung-infiltrating cells using TRIzol (Invitrogen, Carlsbad, CA), according to the manufacturer's instruction. The quality of RNA samples was determined by $1 \%$ agarose gel electrophoresis analysis of 18S, 28S, and tRNA bands for lack of degradation. RNA samples were quantified by spectrophotometry. For real-time PCR analysis, $2.5 \mu \mathrm{g}$ of RNA was reverse-transcribed using a RT First Strand Kit (SABiosciences, Frederick, MD). The generated cDNA samples were then used as the templates for real-time PCR quantification of mRNA expression of 84 mouse genes coding for common proinflammatory cytokines and receptors (RT Profiler PCR Array PAMM-011A, SABiosciences), and of the mouse T-bet gene (PPM03727, SABiosciences), using an $\mathrm{RT}^{2}$ SYBR Green/ROX PCR Master Mix (PA-012, SABiosciences) according to the manufacturer's instruction. Data were analyzed with Bio-Rad iQ5 software.

\section{Quantification and Statistical Analysis}

p52 $\kappa$ B-binding activities in nuclear extracts, as revealed by electrophoretic mobility shifting assay (EMSA), were quantified using ImageJ (version 1.36b). Films were exposed for various times to ensure that all values obtained were within the linear range of the standard curve of optical density established with increasing amounts of the labeled probe. Masson's trichrome staining was quantified by analysis of microscopic images using ImageJ (version 1.36b) as described previously. ${ }^{26}$ Results are expressed as collagen density (area and intensity of trichrome staining/micrometer length of basement membrane of bronchioles with 150- to 200- $\mu \mathrm{m}$ internal diam- eters). At least 10 images of bronchioles from three mice per genotype were quantified. For S100A4 and $\alpha$-smooth muscle actin ( $\alpha \mathrm{SMA})$ staining, positive cells were counted from four to five randomly selected $\times 400$ fields per lung section per mouse, and sections from three mice per genotype were counted. All quantitative data were analyzed for statistical significance between two experimental groups (p52-Tg/p100 ${ }^{-1-}$ versus wild-type, p52-Tg, or $\mathrm{p} 100^{-1-}$ ) by two-tailed Student's $t$-test using Microsoft Excel software. $P<0.05$ was considered significant in all comparisons.

\section{Results}

\section{Negative Feedback Control of p52 Activity by $p 100$}

To confirm the ability of p52 to up-regulate $\mathrm{p} 100$ expression, we examined p100 levels in cells overexpressing p52. Compared with the control cells expressing green fluorescent protein, HT1080 cells overexpressing p52 had significantly higher levels of p100 (Figure 1A, lanes 1 to 3 ). Similar results were obtained with splenocytes isolated from 8-week-old p52-Tg and wild-type littermates (Figure 1A, lanes 4 and 5). Thus, in both cell- and animalbased systems, NF- $\kappa$ B2 expression is regulated in a positive autoregulatory manner.

Given the dual roles of $\mathrm{p} 100$ as the precursor for p52 and an $I_{\kappa} B$ molecule capable of retaining NF- $\kappa$ B molecules in the cytoplasm, the up-regulation of p100 expression could lead to either an increase or a decrease in the nuclear $\kappa \mathrm{B}$-binding activity mediated by p52-containing complexes. We performed EMSA to investigate these possibilities. To focus on NF- $\kappa$ B2 activity, we used nuclear extracts prepared from unstimulated thymocytes of 4-week-old wild-type, p52-Tg, and p52-Tg/p100-/mice. Compared with wild-type extracts (Figure 1B, lane 2), p52-Tg extracts contained significantly higher levels of constitutive $\kappa \mathrm{B}$-binding activity (Figure $1 \mathrm{~B}$, lane 3 ). The predominant $\kappa \mathrm{B}$-binding complexes in p52- $\mathrm{Tg}$ extracts could be supershifted by an antibody against human NF- $\kappa$ B2 (Figure 1B, lanes 6 and 7), indicating that they are p52-containing complexes. Importantly, p52- Tg/ $\mathrm{p} 100^{-1-}$ extracts showed an approximately 2.7 -fold increase in p52-mediated $\kappa \mathrm{B}$-binding activity relative to p52-Tg extracts (Figure 1, B and C), demonstrating that the up-regulation of p100 by p52 led to a decrease in nuclear p52 activity.

To better understand the regulation of nuclear p52 activity by $\mathrm{p} 100$, we examined the protein levels of various NF- $\kappa$ B family members in whole-cell and nuclear extracts prepared from unstimulated thymocytes of 4-week-old wild-type, p52-Tg, p52-Tg/p100-l-, and $\mathrm{p} 100^{-1-}$ mice. Immunoblot analysis of whole-cell extracts revealed that the presence or absence of $\mathrm{p} 100$ had no significant effect on the expression levels of the p52 transgene, NF- $\mathrm{BB} 1 \mathrm{p} 50$, and RelA (Figure 1D). In contrast, there was a substantial decrease in the levels of RelB and, to a lesser extent, c-Rel in $\mathrm{p} 100^{-1-}$ whole-cell extracts. It has been reported recently that p100 and p52 
A

B

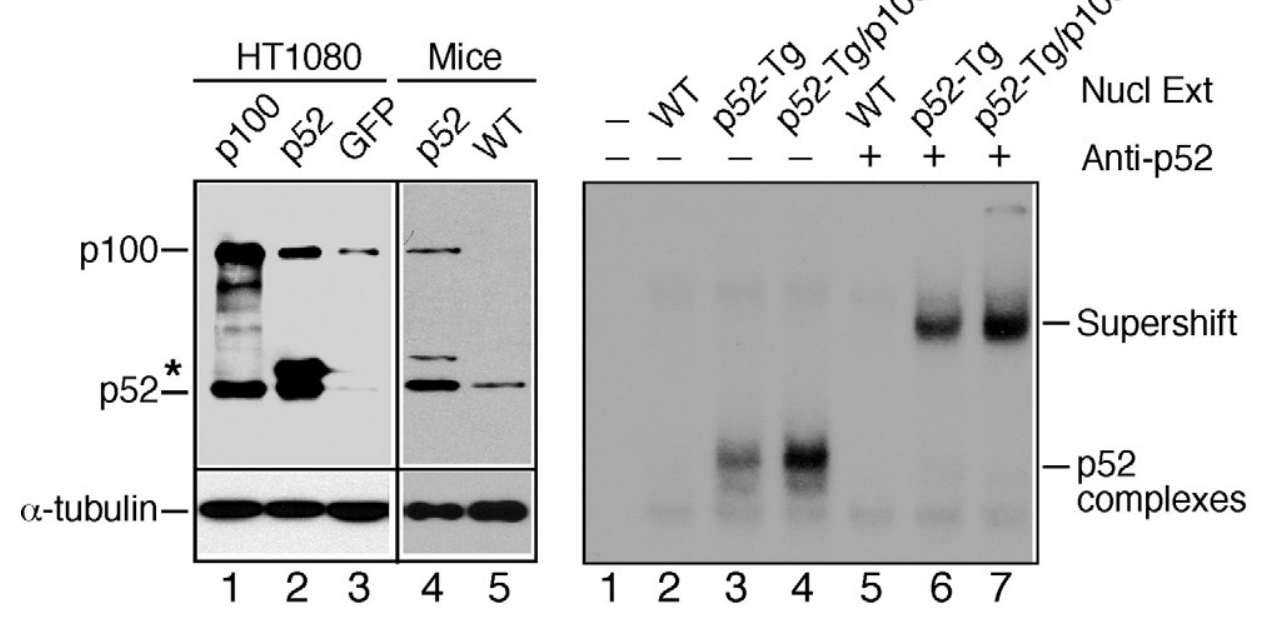

C

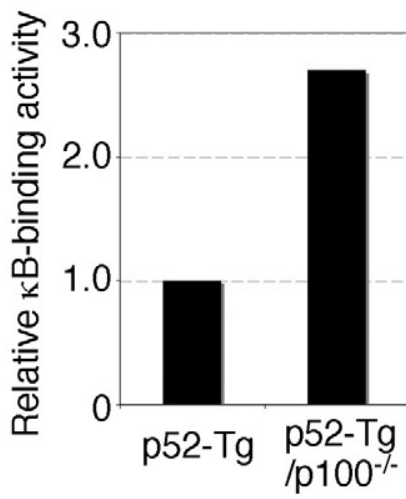

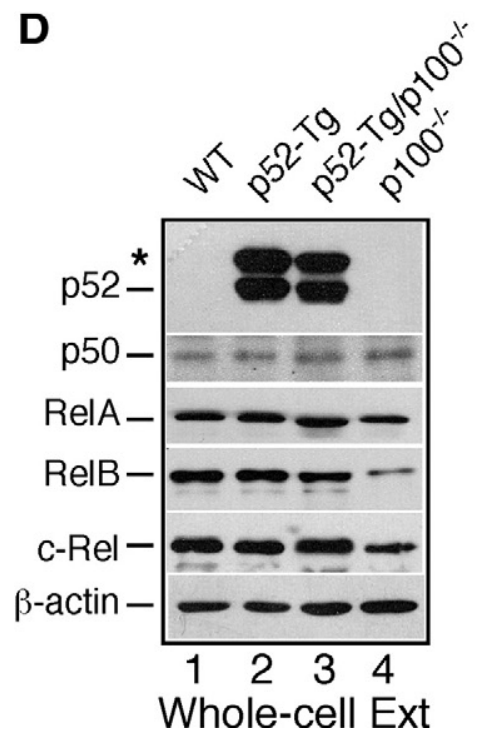

E

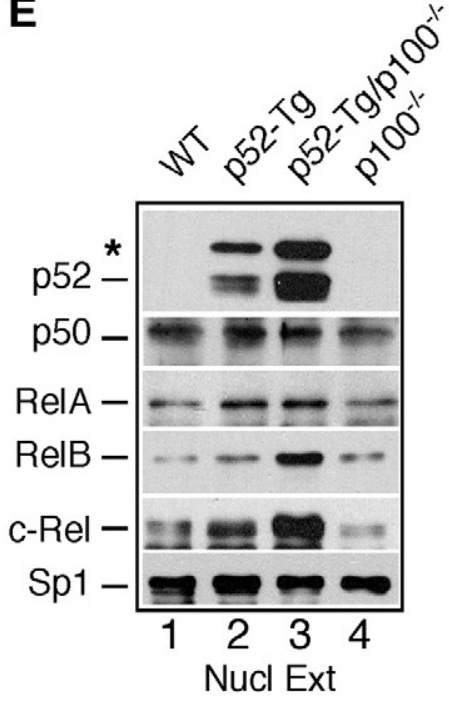

Figure 1. Negative feedback control of p52 activity by p100. A: Immunoblot analysis of NF- $\kappa$ B2 protein levels in HT1080 cells and splenocytes from 8-week-old wild-type (WT) and p52-Tg mice. Asterisk indicates unprocessed product of the p 52 transgene. Levels of $\alpha$-tubulin are shown as loading control. B: EMSA for $\kappa \mathrm{B}$ binding activity in nuclear extracts (Nucl Ext) of thymocytes from 4-week-old wild-type, p52-Tg, and $\mathrm{p} 52-\mathrm{Tg} / \mathrm{p} 100^{-/-}$mice. The $\kappa \mathrm{B}-$ binding complexes containing p 52 are indicated, based on anti-p 52 antibody-mediated supershift. Preimmune rabbit IgG was used as control. C: The $\kappa$ B-binding activity was quantified by densitometry analysis of EMSA films using ImageJ. All values were transformed so that the $\kappa \mathrm{B}$-binding activity in $\mathrm{p} 52$-Tg extracts was equalized to 1.0 Data represent means of two independent experiments. $\mathbf{D}$ and $\mathbf{E}$ : Immunoblot analysis of the NF- $\kappa \mathrm{B}$ family of proteins in thymocyte whole-cell (D) and nuclear (E) extracts from 4-week-old wild-type, $\mathrm{p} 52-\mathrm{Tg}, \mathrm{p} 52-\mathrm{Tg} / \mathrm{p} 100^{-/-}$, and $\mathrm{p} 100^{-/-}$mice. Asterisk indicates unprocessed product of the $\mathrm{p} 52$ transgene. Levels of $\beta$-actin and the basal transcription factor Sp1 are shown as loading control for whole-cell and nuclear extracts, respectively. WT, wild type.

could stabilize RelB. ${ }^{27}$ Our finding suggests that p100 and p52 may have a similar role in stabilization of c-Rel protein. Importantly, in agreement with the finding of EMSA (Figure 1, B and C), p52-Tg/p100-/- nuclear extracts showed significantly higher levels of p52, RelB, and c-Rel in comparison with p52-Tg nuclear extracts (Figure 1E), indicating that the presence of p100 inhibited the nuclear translocation of p52, RelB, and c-Rel proteins. We obtained similar results with whole-cell and nuclear extracts of mouse splenocytes (data not shown). Taken together, these results suggest that NF- $\kappa$ B2 signaling is controlled by a negative feedback loop.

\section{Development of Fatal Lung Inflammation in p52-Tg/p100 ${ }^{-1-}$ Mice}

To assess the biological significance of this negative feedback control loop, we analyzed the phenotypes of p52-Tg mice with or without p100 expression. We have recently reported that $\mathrm{p} 100^{-1-}$ and $\mathrm{p} 52-\mathrm{Tg}$ mice are prone to the development of inflammatory autoimmune disease but have a life span similar to that of their wild- type littermates $^{18,25}$ (Figure 2A). In addition, p52-Tg mice heterozygous for $\mathrm{p} 100\left(\mathrm{p} 52-\mathrm{Tg} / \mathrm{p} 100^{+/-}\right)$had a mortality rate similar to that of p52-Tg mice (data not shown). In contrast, $\mathrm{p} 52-\mathrm{Tg} / \mathrm{p} 100^{-1-}$ mice had a mortality rate of $75 \%$ by 64 weeks (Figure 2A).

To determine the cause of the premature death of p52-Tg/p100-1- mice, we performed histological examination of major organs from $\mathrm{p} 52-\mathrm{Tg} / \mathrm{p} 100^{-1-}$ mice at various ages, in comparison with their age-matched wildtype, p52-Tg, and p100-/- littermates. We observed no consistent histopathological changes in major organs of p52-Tg/p100-1- mice including the liver, kidney, bone marrow, and stomach (data not shown). However, p52$\mathrm{Tg} / \mathrm{p} 100^{-1-}$ mice developed severe lung inflammation in a time-dependent manner (Figure 2B). For mice sacrificed at the age of 4 weeks, there was no significant difference in the lung histological appearance between $\mathrm{p} 52-\mathrm{Tg} / \mathrm{p} 100^{-1-}$ mice and their control littermates (Figure $2 \mathrm{~B}$, top panel). When sacrificed at 8 weeks, the lungs of p52-Tg/p100-1- mice displayed marked infiltration of predominantly lymphocytes, as judged by morphology (Figure 2B, middle panel). For all moribund p52-Tg/ 
A

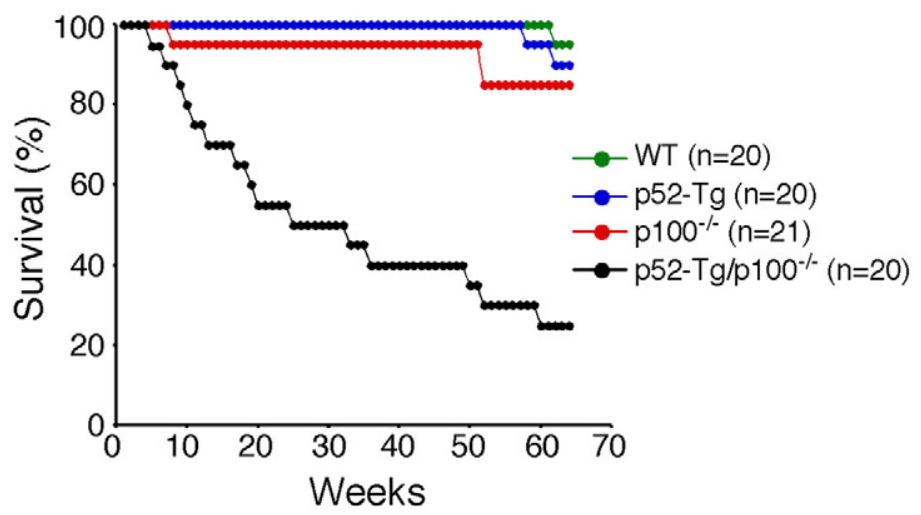

Figure 2. Development of fatal lung inflammation in $\mathrm{p} 52-\mathrm{Tg} /$ $\mathrm{p} 100^{-/-}$mice. A: Survival curve of $\mathrm{p} 52-\mathrm{Tg} / \mathrm{p} 100^{-/-}$mice and their wild-type (WT), p52-Tg, and p100 ${ }^{-/-}$littermates. Numbers of mice for each group are indicated. B: H\&E staining of formalin-fixed lung sections from wild-type, p52-Tg, p52-Tg/p100 ${ }^{-1-}$, and $\mathrm{p} 100^{-1}$ littermates at the indicated ages. Scale bars $=400 \mu \mathrm{m}$. C: H\&E staining of formalin-fixed lung sections from representative mor ibund $\mathrm{p} 52-\mathrm{Tg} / \mathrm{p} 100^{-1-}$ mice at the indicated ages. Scale bar $=$ $100 \mu \mathrm{m}$.

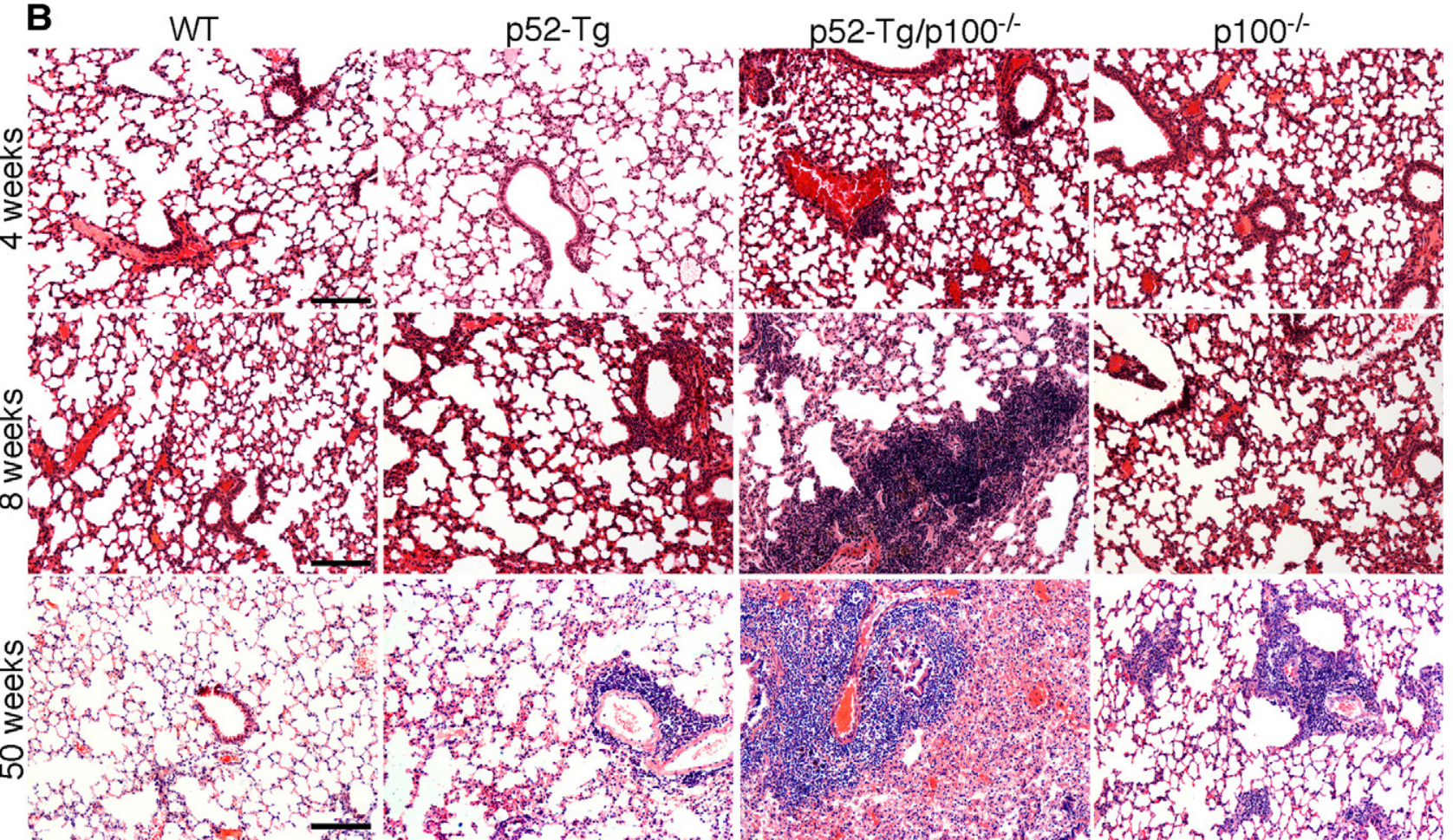

C

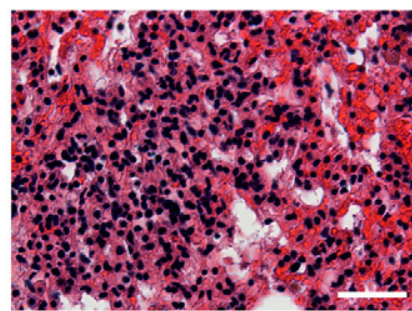

\#5916-18 weeks

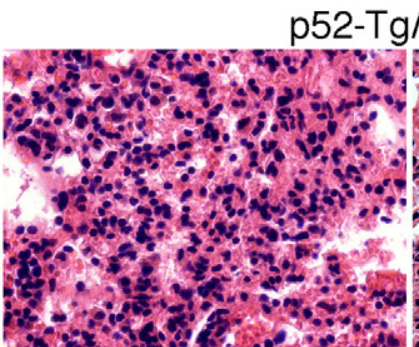

\#6247-25 weeks

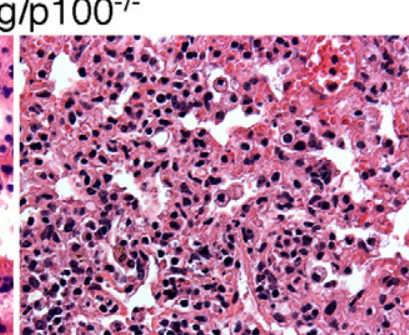

\#6250-35 weeks

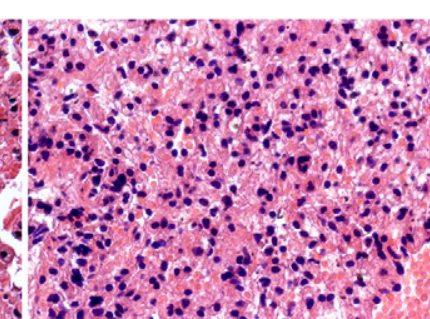

\#5905-50 weeks $\mathrm{p} 100^{-1-}$ mice, regardless of their ages, the primary pathological change seen in the lungs was diffuse alveolar damage characterized by pronounced pulmonary edema, type II pneumocyte hyperplasia, fibrin-like deposits in alveolar spaces, and interstitial thickening in the lung tissue, leading to collapse of alveoli and consolidation of the lung (Figure 2, B, bottom panel, and C). The diffuse alveolar damage was specific to $\mathrm{p} 52-\mathrm{Tg} / \mathrm{p} 100^{-/-}$ mice. Although p52-Tg and $\mathrm{p} 100^{-1-}$ mice at old ages ( $\geq 50$ weeks) are prone to the development of lung inflammation characterized by infiltration of activated lymphocytes, their lung architecture is typically preserved $^{18,25}$ (Figure 2B)

In addition, Masson's trichrome staining of lung sections revealed the development of peribronchial fibrosis in $\mathrm{p} 52-\mathrm{Tg} / \mathrm{p} 100^{-1-}$ mice in a similar time-de- 

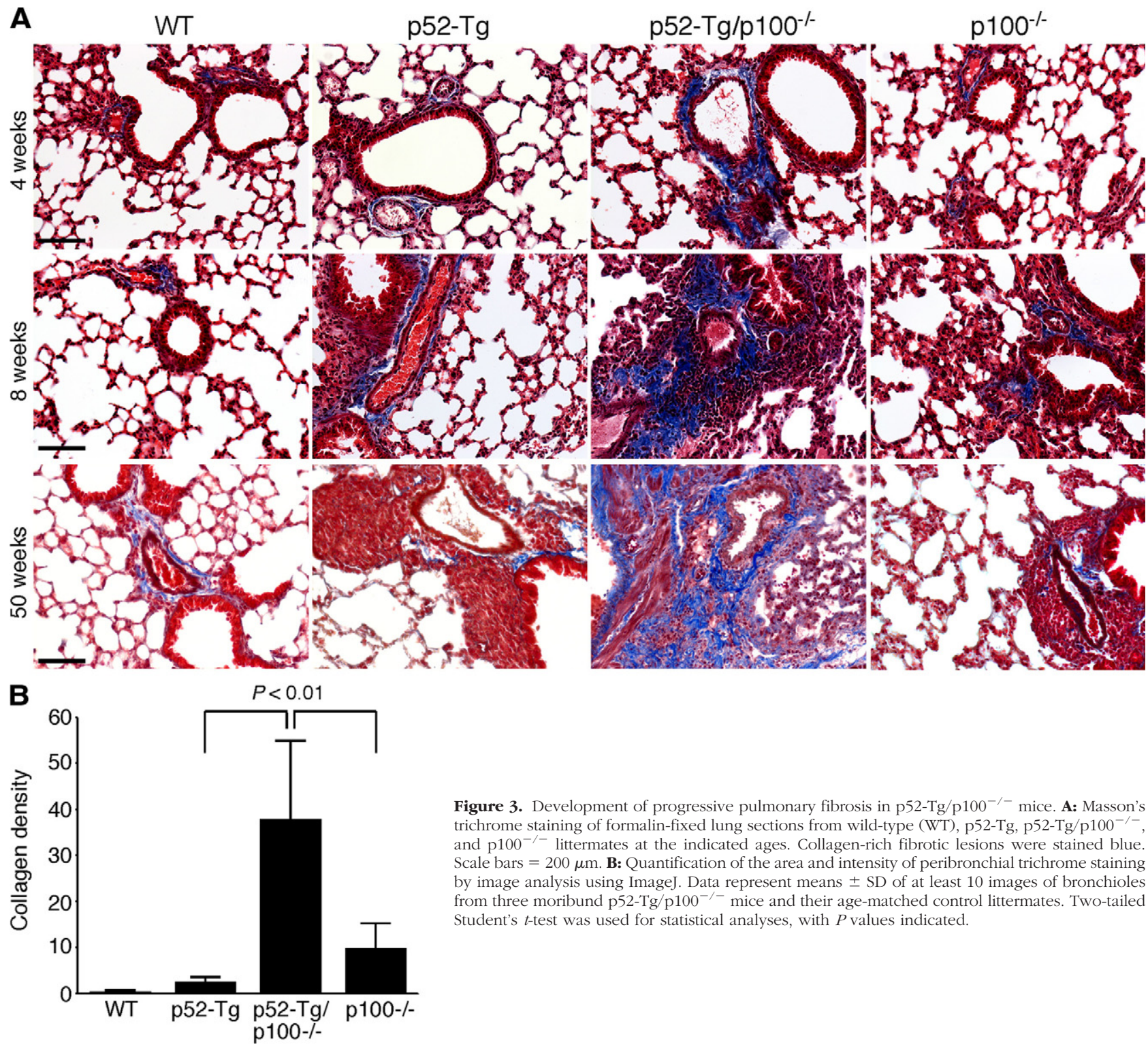

\begin{abstract}
Figure 3. Development of progressive pulmonary fibrosis in $\mathrm{p} 52-\mathrm{Tg} / \mathrm{p} 100^{-1-}$ mice. A: Masson's trichrome staining of formalin-fixed lung sections from wild-type (WT), p52-Tg, p52-Tg/p100 ${ }^{-1}$ and $\mathrm{p} 00^{-1-}$ littermates at the indicated ages. Collagen-rich fibrotic lesions were stained blue. Scale bars $=200 \mu \mathrm{m}$. B: Quantification of the area and intensity of peribronchial trichrome staining by image analysis using ImageJ. Data represent means \pm SD of at least 10 images of bronchioles from three moribund $\mathrm{p} 52-\mathrm{Tg} / \mathrm{p} 100^{-/-}$mice and their age-matched control littermates. Two-tailed Student's $t$-test was used for statistical analyses, with $P$ values indicated.
\end{abstract}

pendent manner (Figure 3A). Quantification of microscopic images of lung sections stained with Masson's trichrome using ImageJ software showed significantly higher levels of peribronchial collagen content in moribund $\mathrm{p} 52-\mathrm{Tg} / \mathrm{p} 100^{-1-}$ mice relative to the levels in the age-matched control littermates (Figure 3B). The widespread diffuse alveolar damage in combination with lung fibrosis was probably a major cause of the premature death of $\mathrm{p} 52-\mathrm{Tg} / \mathrm{p} 100^{-1-}$ mice. Thus, the presence of p100 significantly reduced the lung tissue damage caused by constitutive activation of p52 in Iymphocytes.

\section{Lymphocyte Infiltration in the Lungs of p52-Tg/p100-1- Mice}

To shed light on the cellular basis of the fatal lung inflammation, we examined the infiltrating lymphocytes in the lungs of moribund p52-Tg/p100 ${ }^{-1-}$ mice. Immunohisto- chemical staining revealed that the infiltrating lymphocytes consisted of both $B$ and $T$ cells (Figure 4A), although $T$ cells seemed to be predominant in most of the lung specimens. We also isolated infiltrating cells from the lungs of $\mathrm{p} 52-\mathrm{Tg} / \mathrm{p} 100^{-1-}$ mice and their wild-type, $\mathrm{p} 52-\mathrm{Tg}$, and $\mathrm{p} 100^{-1-}$ littermates at the age of 6 months ( $n=3$ per genotype) and quantified lymphocyte subpopulations by flow cytometry (Figure 4, B-D). The lungs of $\mathrm{p} 52-\mathrm{Tg} / \mathrm{p} 100^{-1-}$ mice contained significantly more lymphocytes in comparison with those of their control littermates, and approximately $75 \%$ of them were $\mathrm{CD}^{+} \mathrm{T}$ cells (Figure 4B). Staining for the memory marker CD44 and the activation marker CD69 also revealed significant increases in the numbers of memory and activated CD4 ${ }^{+}$ helper T cells and of memory $\mathrm{B}^{2} 2 \mathrm{O}^{+} \mathrm{B}$ cells in the lungs of $\mathrm{p} 52-\mathrm{Tg} / \mathrm{p} 100^{-1-}$ mice relative to those of their control littermates (Figure 4, C and D). These data suggest that the lymphocyte infiltration in the lungs of $\mathrm{p52}-\mathrm{Tg} / \mathrm{p} 100^{-1-}$ mice was the result of ongoing immune responses, which 
A

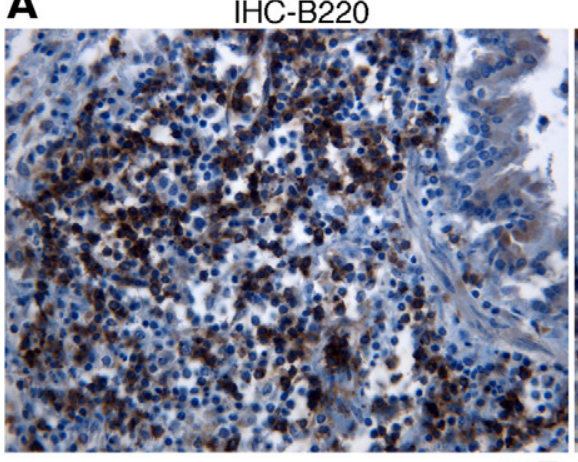

$\mathrm{p} 52-\mathrm{Tg} / \mathrm{p} 100^{-1-}$

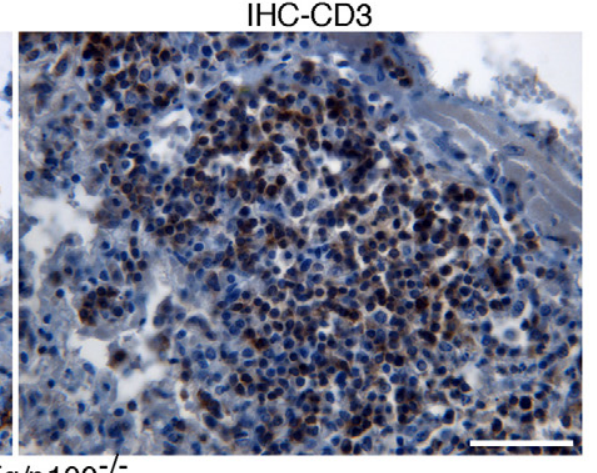

IHC-CD3

B

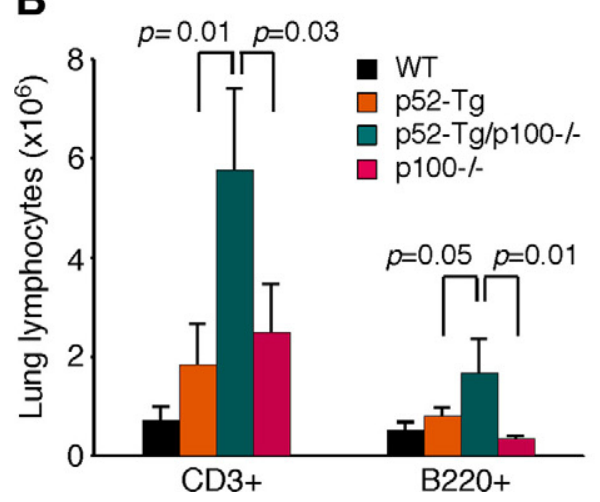

C

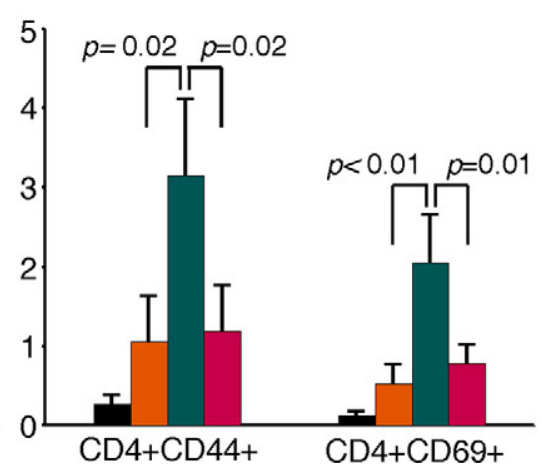

D $p=0.02 p<0.01$

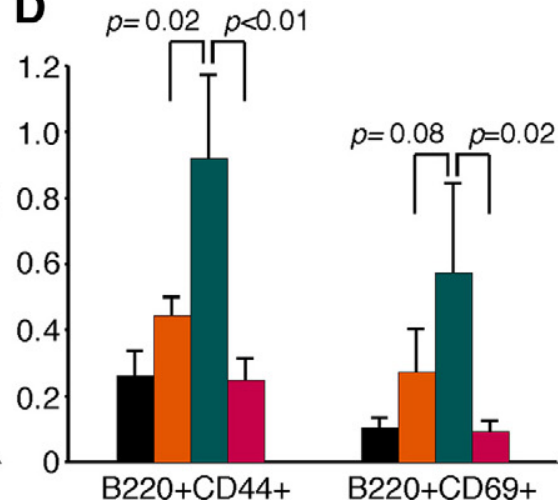

Figure 4. Lymphocyte infiltration in the lungs of $\mathrm{p} 52-\mathrm{Tg} / \mathrm{p} 100^{-/-}$mice. A: Immunohistochemical (IHC) staining of formalin-fixed lung sections of a moribund p52-Tg/p100 ${ }^{-/-}$mouse (25 weeks). Most infiltrating cells stained positively either for CD3, a T-cell marker, or B220, a B-cell marker. Scale bar $=100 \mu \mathrm{m}$. B-D Flow cytometry quantification of lung-infiltrating lymphocyte populations of 6-month-old p52-Tg/p100 ${ }^{-1-}$ mice and their age-matched wild-type, p52-Tg and $\mathrm{p} 100^{-/}$littermates. Data represent means \pm SD from three mice per genotype. Two-tailed Student's $t$-test was used for statistical analyses, with $P$ values indicated.

were much less severe in the presence of p100, indicating a critical role of p100 in limiting the lung immune response resulting from constitutive activation of p52 in lymphocytes.

\section{Macrophage Infiltration in the Lungs of p52-Tg/p100-1- Mice}

Alveolar macrophages play an important role in lung inflammatory responses. ${ }^{28}$ Therefore, we performed immunohistochemical staining of lung sections for F4/80, a marker for mouse mature macrophages. ${ }^{29}$ Compared with wild-type, p52-Tg, and $\mathrm{p} 100^{-1-}$ mice, there was a marked increase in the number of F4/80-expressing macrophages in the alveoli and interstitium of p52-Tg/ p100 ${ }^{-1-}$ mice (Figure 5A). We also quantified the number of $\mathrm{F} 4 / 80^{+}$macrophages by flow cytometry analysis of lung-infiltrating cells isolated from 6-month-old wild-type, p52-Tg, p52-Tg/p100 ${ }^{-1-}$, and $\mathrm{p} 100^{-/-}$mice $(n=3$ per genotype). Consistent with the result of immunohistochemical staining, the lungs of $\mathrm{p} 52-\mathrm{Tg} / \mathrm{p} 100^{-1-}$ mice contained an average of 7.6-, 5.8-, and 3.3-fold more $\mathrm{F} 4 / 80^{+}$macrophages than their wild-type, p52-Tg, and p100 ${ }^{-1-}$ littermates, respectively (Figure 5B). Thus, in the absence of $\mathrm{p} 100$, constitutive activation of p52 in lymphocytes led to marked macrophage infiltration in the lung, which may play an important role in the development of diffuse alveolar damage in $\mathrm{p} 52-\mathrm{Tg} / \mathrm{p} 100^{-1-}$ mice.

\section{Accumulation of Fibroblasts and Myofibroblasts in the Lungs of $\mathrm{p} 52-\mathrm{Tg} / \mathrm{p} 100^{-1-}$ Mice}

As described above, moribund p52-Tg/p100-1- mice showed prominent peribronchial fibrosis (Figure 3). This observation prompted us to examine the extents of fibroblasts and myofibroblasts in the lungs of moribund p52$\mathrm{Tg} / \mathrm{p} 100^{-1-}$ mice in comparison with their age-matched wild-type, p52-Tg, and p100-/- littermates. We first examined lung sections by immunohistochemical staining for S100A4, also known as fibroblast-specific protein 1, ${ }^{30}$ a marker for lung fibroblasts. ${ }^{31,32}$ In the wild-type lung, $\mathrm{S} 100 \mathrm{~A}^{+}{ }^{+}$resident fibroblasts were found in the adventitia of vascular vessels, as well as in the lung interstitium and along alveolar walls (Figure 6A). A modest increase in the number of fibroblasts was observed in the lungs of

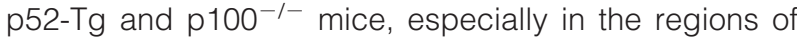
heavy mononuclear cell infiltration (Figure 6A). In contrast, the lungs of $\mathrm{p} 52-\mathrm{Tg} / \mathrm{p} 100^{-1-}$ mice showed a significant accumulation of $\mathrm{S} 100 \mathrm{~A}^{+}$fibroblasts, primarily in the perivascular and peribronchial regions (Figure 6A), where prominent fibrosis was also observed (Figure 3A). Quantitative analysis showed an approximately twofold increase in the number of S100A4 ${ }^{+}$fibroblasts in the lungs of $\mathrm{p} 52-\mathrm{Tg} / \mathrm{p} 100^{-1-}$ mice, compared with $\mathrm{p} 52-\mathrm{Tg}$ and $\mathrm{p} 100^{-1-}$ littermates (Figure 6C).

We next examined lung sections for the presence of myofibroblasts, given their important role in the patho- 
A

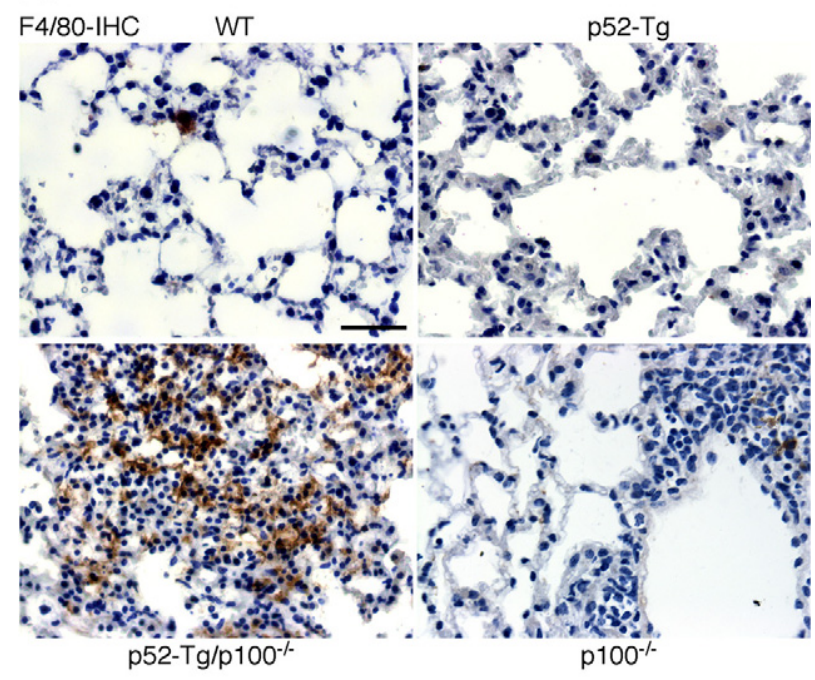

B

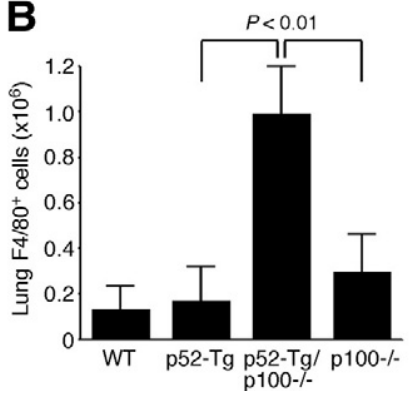

Figure 5. Macrophage infiltration in the lungs of $\mathrm{p} 52-\mathrm{Tg} / \mathrm{p} 100^{-/-}$mice. A: Immunohistochemical (IHC) staining of formalin-fixed lung sections of a moribund $\mathrm{p} 52-\mathrm{Tg} / \mathrm{p} 100^{-1-}$ mouse (25 weeks) and its age-matched wild-type (WT), p52-Tg, and $\mathrm{p} 100^{-/-}$littermates for $\mathrm{F} 4 / 80$, a marker for alveolar macrophages. Scale bar $=100 \mu \mathrm{m}$. B: Flow cytometry quantification of lung $\mathrm{F} 4 / 80^{+}$macrophages of 6 -month-old $\mathrm{p} 52-\mathrm{Tg} / \mathrm{p} 100^{-1-}$ mice and their agematched wild-type, p52-Tg and $\mathrm{p} 100^{-/-}$littermates. Data represent means \pm SD from three mice per genotype. Two-tailed Student's $t$-test was used for statistical analyses, with $P$ values indicated.

genesis of lung fibrosis. ${ }^{33}$ Myofibroblasts, also termed "activated fibroblasts," are commonly identified by their expression of $\alpha$ SMA. ${ }^{34,35}$ We observed very few $\alpha \mathrm{SMA}^{+}$ myofibroblasts in the lung sections of wild-type, p52-Tg, and $\mathrm{p}_{100^{-1-}}$ mice (Figure 6B). However, the lung sections of $\mathrm{p} 52-\mathrm{Tg} / \mathrm{p} 100^{-1-}$ mice showed a marked increase in the number of $\alpha \mathrm{SMA}^{+}$myofibroblasts (Figure $6, \mathrm{~B}$ and C). Thus, in the absence of p100, constitutive activation of p52 signaling in lymphocytes promoted the accumulation of fibroblasts and myofibroblasts in the lung.

\section{Induction of the $T_{H} 1$ Cytokine IFN- $\gamma$ and Its Inducible Proinflammatory Chemokines in the Lungs of $\mathrm{p} 52-\mathrm{Tg} / \mathrm{p} 100^{-1-}$ Mice}

To understand the molecular mechanism underlying the fatal lung inflammation in p52-Tg/p100-1- mice, we examined mRNA expression levels of 84 proinflammatory cytokines and chemokines in lung tissues of 4-month old mice by quantitative real-time PCR. A large number of cytokines and chemokines and their receptors showed significant up-regulation in $\mathrm{p} 52-\mathrm{Tg} / \mathrm{p} 100^{-1-}$ mice com- pared with their wild-type, p52-Tg, and $\mathrm{p} 100^{-1-}$ littermates (Figure 7, A-C).

A prominent feature of the cytokine and chemokine response in the lungs of $\mathrm{p} 52-\mathrm{Tg} / \mathrm{p} 100^{-1-}$ mice was the high-level induction of IFN- $\gamma$ and its inducible chemokines CXCL9 and CXCL10 (Figure 7A). The expression of CXCR3, the receptor for both CXCL9 and CXCL10, was also up-regulated (Figure 7C). Other IFN- $\gamma$-inducible chemokines, ${ }^{36}$ including CCL2, CCL3, CCL4, and CCL5, and their receptors CCR1, CCR2, CCR3, and CCR5, were also significantly up-regulated in the lungs of p52Tg/p100 ${ }^{-1-}$ mice (Figure 7, A and C). To confirm the result of real-time PCR assays, we examined the protein levels of CXCL9, CCL2, and CCL5 by immunohistochemical staining of lung sections. Age-matched wild-type, p52-Tg, and $\mathrm{p} 100^{-1-}$ mice showed no or few cells staining positively for these chemokines, whereas p52-Tg/p100-/sections showed significant numbers of mononuclear cells expressing CXCL9, CCL2, or CCL5 (Figure 7B).

IFN- $\gamma$ is a potent inflammatory cytokine produced primarily by $T_{H} 1$ cells. ${ }^{37}$ Its expression in $T_{H} 1$ cells is controlled by T-bet, a $\mathrm{T}$ box transcription factor with a critical role in the development and maintenance of $T_{H} 1$ cells. ${ }^{38}$ Real-time PCR analysis revealed an approximately 3-fold increase in T-bet mRNA levels in infiltrating cells isolated from the lungs of $\mathrm{p} 52-\mathrm{Tg} / \mathrm{p} 100^{-1-}$ mice, compared with the cells from age-matched wild-type, p52-Tg, and p100-/- littermates (Figure 7D). We observed no significant difference between the mice in levels of $\mathrm{T}_{\mathrm{H}^{2}}$ cytokines, such as IL-4 and IL13 and of IL-17 (Figure 7A), a cytokine produced specifically by $T_{H} 17$ cells that have an important role in immune responses to infectious agents and in various autoimmune diseases. ${ }^{39}$ Taken together, these results indicate that the fatal lung inflammation in p52-Tg/p100 ${ }^{-1-}$ mice was associated with high-level induction of $T_{H} 1$ cytokines and chemokines.

\section{Discussion}

It is well documented that p100 can function as an $\mid \kappa \mathrm{B}$ molecule, ${ }^{4,11-14}$ and p100 expression can be up-regulated by its processed product $\mathrm{p} 52 .^{16,17}$ In the present study, we confirm these observations in both in vitro and in vivo systems, showing that cells expressing higher levels of p52 also had higher levels of p100. Moreover, we show that abrogation of this positive autoregulation leads to a marked increase in the nuclear p52 $\kappa$ B-binding activity, suggesting that the autoregulation acts as a negative feedback loop for the control of NF- $\kappa \mathrm{B} 2$ activity. Finally, we present genetic evidence that this negative feedback control mechanism has a critical role in limiting the inflammatory effect of sustained activation of NF- $\kappa \mathrm{B} 2$ signaling. Mice deficient in NF- $\kappa$ B2 p100 but with constitutive expression of p52 in lymphocytes developed fatal lung inflammation, whereas their littermates with only p100 deficiency or p52 expression in lymphocytes developed mild lung inflammation at old ages and had a life span similar to that of their wild-type littermates.

The primary pathological change seen in the lungs of $\mathrm{p} 52-\mathrm{Tg} / \mathrm{p} 100^{-1-}$ mice is diffuse alveolar damage with 
A
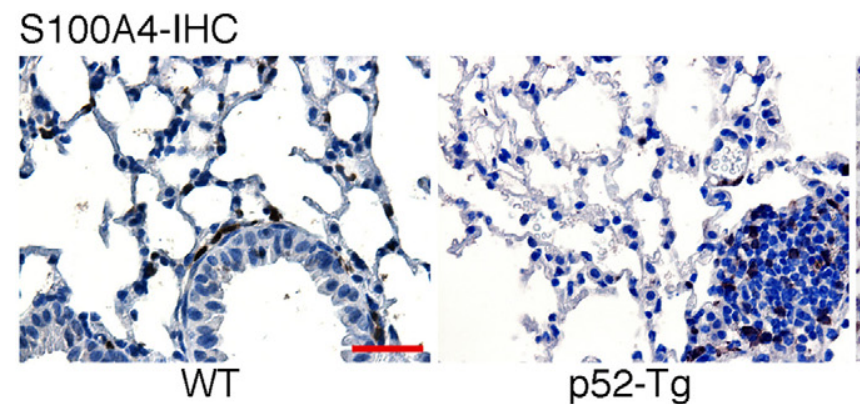

p52-Tg

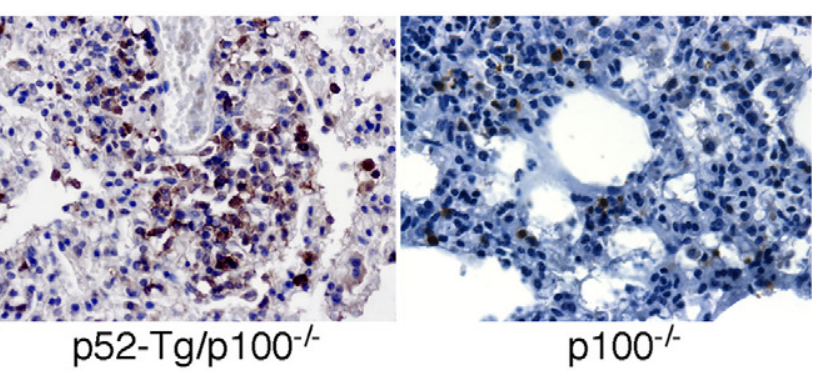

B

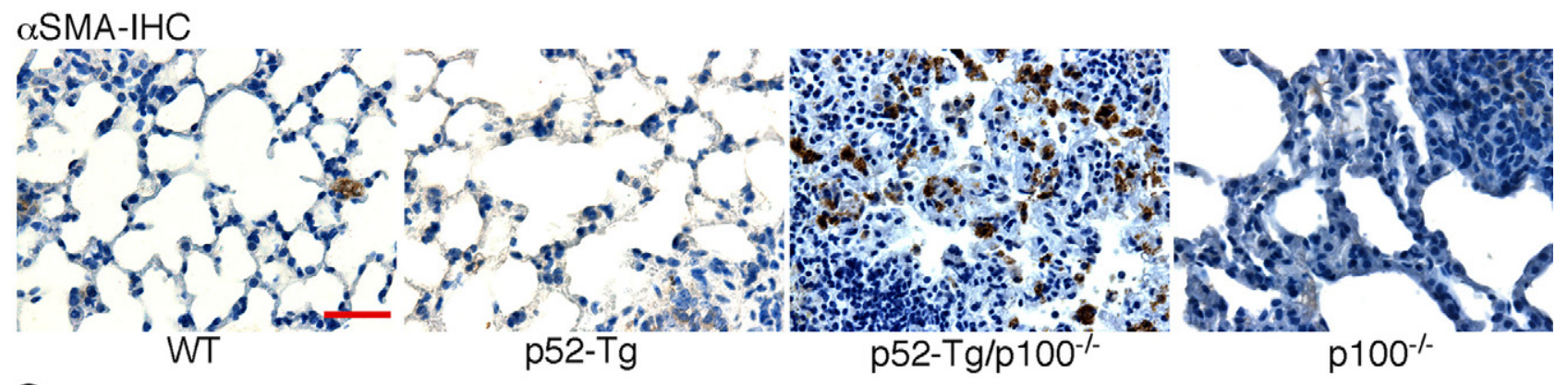

C

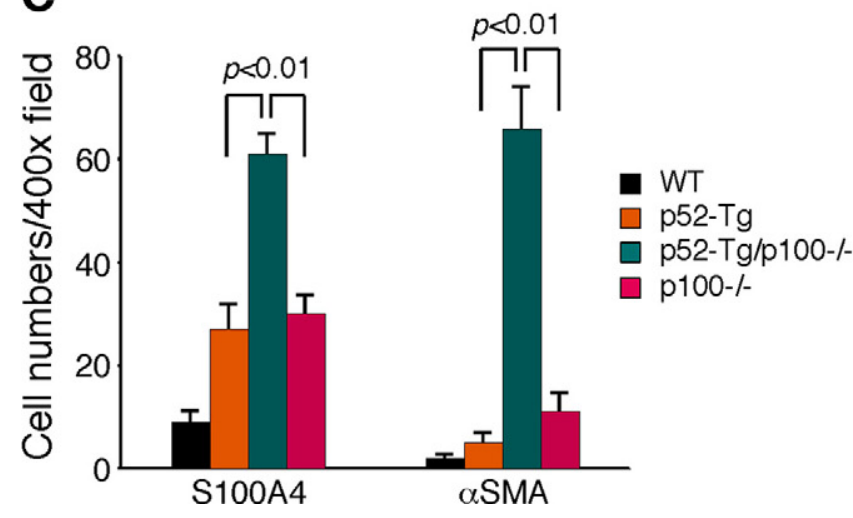

Figure 6. Accumulation of fibroblasts and myofibroblasts in the lungs of $\mathrm{p} 52-\mathrm{Tg} / \mathrm{p} 100^{-1-}$ mice. Immunohistochemical (IHC) staining of formalinfixed lung sections of a moribund $\mathrm{p} 52-\mathrm{Tg} / \mathrm{p} 100^{-/-}$mouse ( 50 weeks) and its age-matched wild-type (WT), p52-Tg, and p100-/- littermates for S100A4 (A), a marker for lung resident fibroblasts, and for $\alpha$-SMA (B), a marker for myofibroblasts. Scale bar $=100 \mu \mathrm{m}$. C: Average numbers of $5100 \mathrm{~A}^{+}$and $\alpha$-SMA ${ }^{+}$cells per $\times 400$ field. Data represent means $\pm \mathrm{SD}$ of 12 to 15 fields from three mice per genotype. A Two-tailed Student's $t$-test was used for statistical analyses, with $P$ values indicated.

localized fibrosis, leading to alveolar collapse and lung consolidation. The lung-specific inflammation observed in $\mathrm{p} 52-\mathrm{Tg} / \mathrm{p} 100^{-1-}$ mice remains a puzzle. We speculate that the constant exposure to antigenic stimuli, such as airborne microorganisms and particles, might make the lung more vulnerable to aberrant immune and inflammatory responses caused by constitutive activation of NF- $\kappa$ B2 signaling in lymphocytes. This notion is consistent with the observation that the infiltrating lymphocytes in the lungs of $\mathrm{p} 52-\mathrm{Tg} / \mathrm{p} 100^{-1-}$ mice consisted predominantly of memory and activated $\mathrm{CD}^{+} \mathrm{T}$ helper cells, suggesting ongoing $T$ cell-mediated immune responses.

Several lines of evidence suggest that $T_{H} 1$ cells play a major role in causing the lung inflammation in p52-Tg/

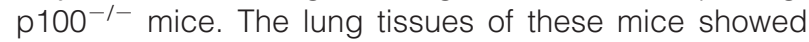
consistently high-level induction of the $T_{H} 1$ cytokine IFN- $\gamma$ and its inducible chemokines. In agreement with the finding, infiltrating cells isolated from the lungs of p52-Tg/ p100-1- mice showed significantly higher mRNA levels of T-bet, a transcription factor specifically required for
IFN- $\gamma$ production in $\mathrm{T}_{\mathrm{H}} 1$ cells. ${ }^{38} \mathrm{We}$ also observed significant up-regulation of CXCR3 and CCR5 in the lung tissues, which are preferentially expressed on polarized $\mathrm{T}_{\mathrm{H}} 1$ cells. ${ }^{40}$ Finally, the lung inflammation in p52-Tg/ $\mathrm{p} 100^{-1-}$ mice is histologically similar to, although much severe than, the lung injury observed in mice transferred with alloreactive $T_{H} 1$ cells, which is characterized by widespread perivascular and interstitial infiltration of mononuclear cells and alveolitis. ${ }^{41,42}$ These findings also suggest that $\mathrm{NF}-\kappa \mathrm{B} 2$ signaling may have a key role in the development of $\mathrm{T}_{\mathrm{H}} 1$ cells.

Recruitment and activation of macrophages are important in inflammatory responses. IFN- $\gamma$-inducible chemokines, such as CXCL10, CCL2, CCL3, CCL4, and CCL5, play a prominent role in recruiting monocytes and macrophages. ${ }^{36}$ All of these chemokines were significantly up-regulated in the lungs of p52-Tg/p100-/- mice. In addition, IFN- $\gamma$ is a major macrophage-activating cytokine. ${ }^{36,43}$ We also observed a significant increase in tumor necrosis factor- $\alpha$ (TNF $\alpha$ ) expression in the lungs of 


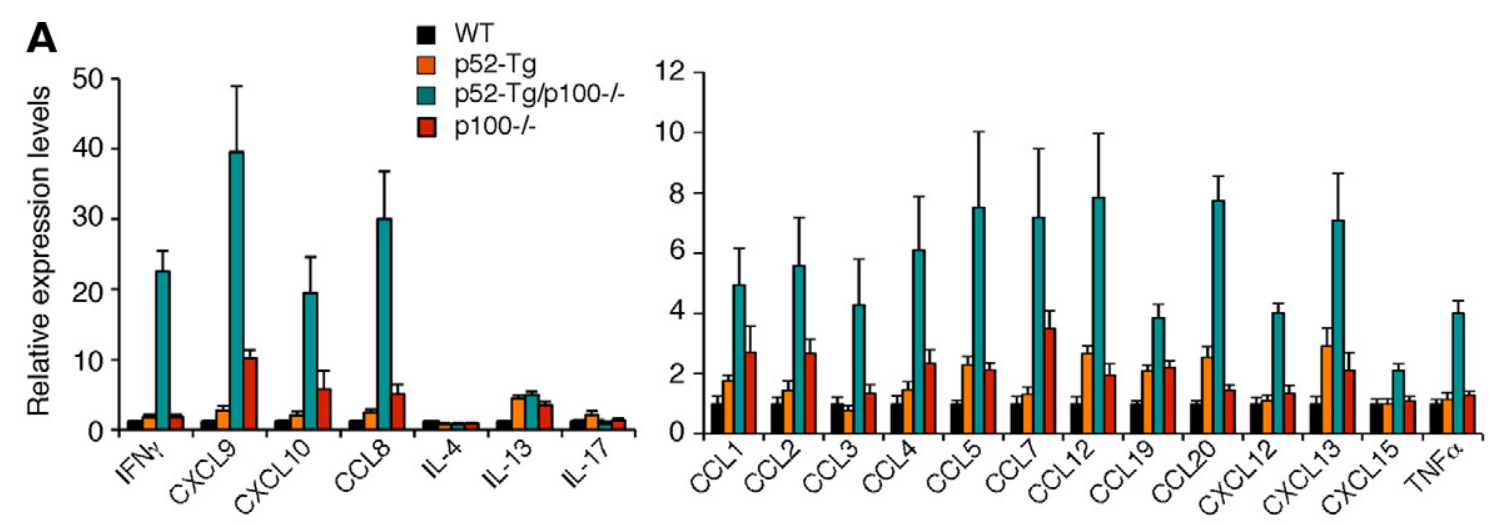

B WT $\quad$ W52-T

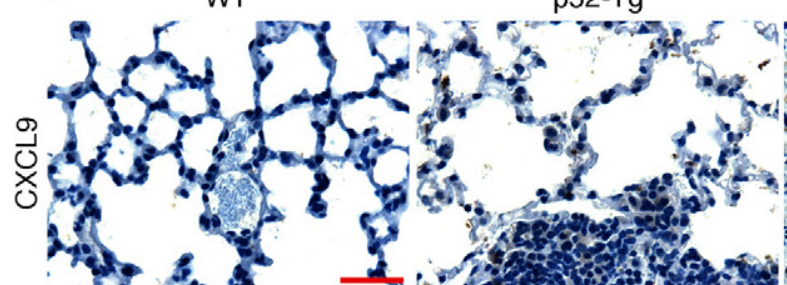

$\mathrm{p} 52-\mathrm{Tg} / \mathrm{p} 100^{-/-}$

p $100^{-/}$
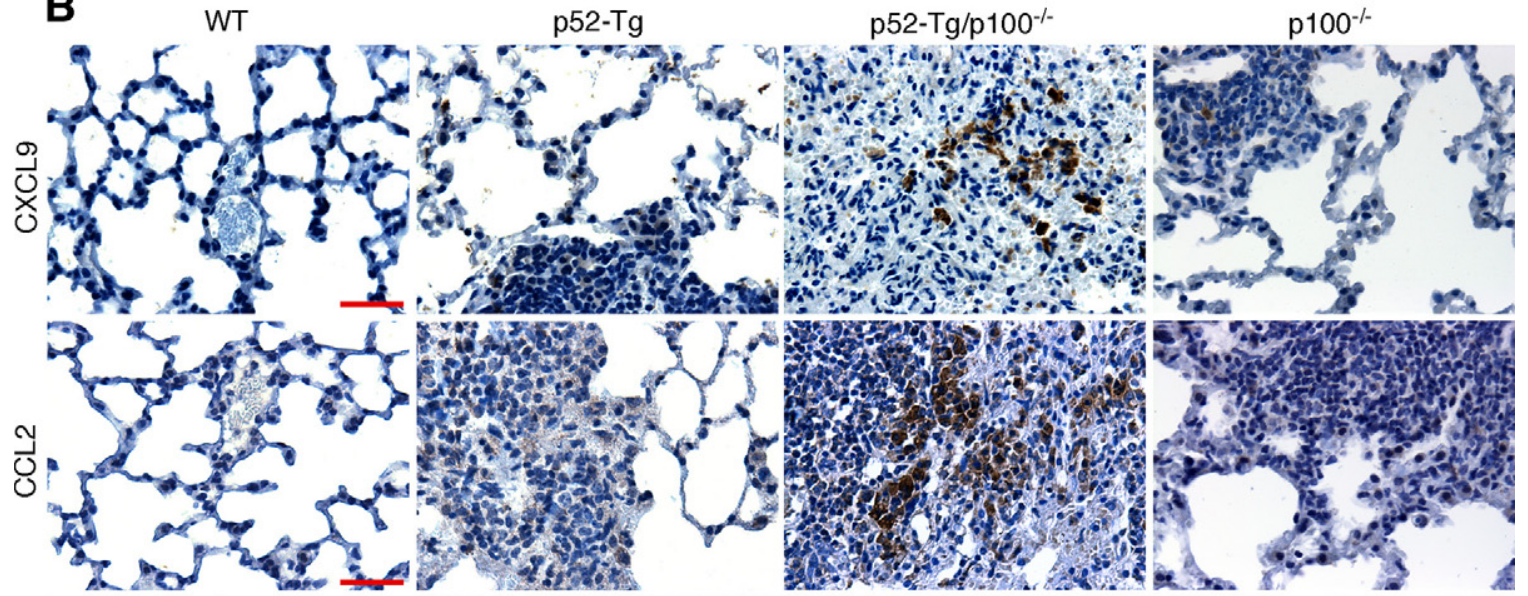

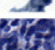


C
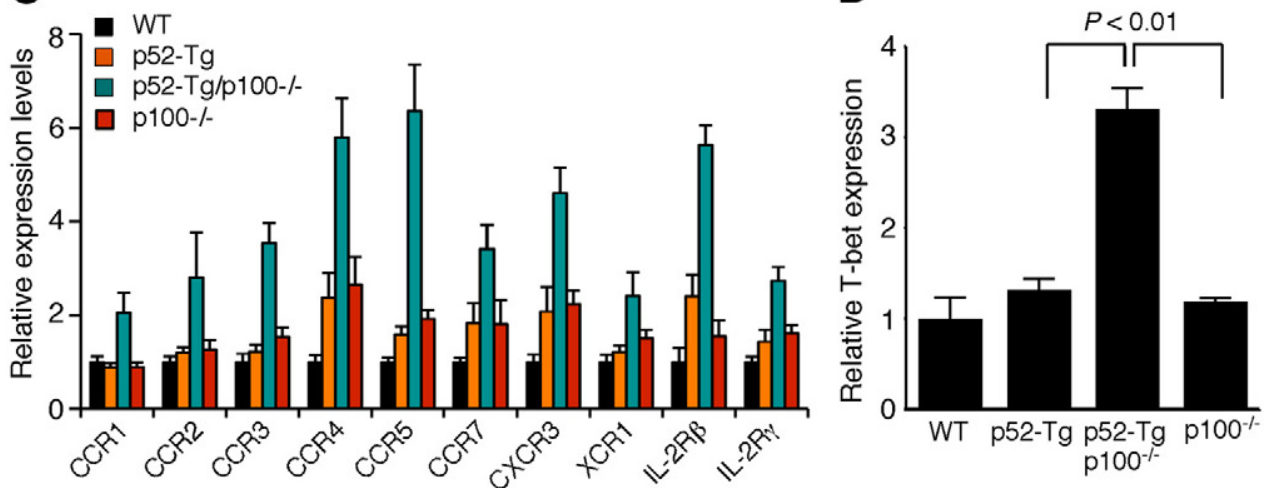

Figure 7. Induction of proinflammatory cytokines and chemokines in the lungs of $\mathrm{p} 52-\mathrm{Tg} / \mathrm{p} 100^{-/-}$mice. A: Quantitative real-time PCR analysis of mRNA levels of proinflammatory cytokines and chemokines in the lungs of $\mathrm{p} 52-\mathrm{Tg} / \mathrm{p} 100^{-1}$ mice and their wild-type (WT), p52-Tg, and p100-- littermates at the age of 4 months ( $n=3$ per genotype). B: Immunohistochemical staining of formalin-fixed lung sections from 4-month-old p52-Tg/p100 ${ }^{-1-}$ mice and their age-matched wild-type, p52-Tg, and p100 ${ }^{-1-}$ littermates for CXCL9, CCL2, and CCL5. Scale bars $=100 \mu \mathrm{m}$. C: Quantitative real-time PCR analysis of mRNA levels of receptors for the proinflammatory cytokines and chemokines in the lungs of $\mathrm{p} 52-\mathrm{Tg} / \mathrm{p} 100^{-1-}$ mice and their wild-type, $\mathrm{p} 52-\mathrm{Tg}$, and littermates at the age of 4 months $(n=$ 3 per genotype). D: Quantitative real-time PCR analysis of T-bet mRNA levels in lung-infiltrating cells from 6-month-old wild-type, p52-Tg, p52-Tg/p100-/- , and p100 ${ }^{-1-}$ littermates $(n=3$ per genotype). All values were transformed so that the mRNA levels in the wild-type mice were equalized to 1.0 . Data were analyzed for statistical significance by a two-tailed Student's $t$-test. For all of the real-time PCR data presented, the differences in mRNA levels between p52-Tg/p100 ${ }^{-/-}$mice and their control littermates are statistically significant $(P<0.05)$, except for interleukin (IL)-4, interleukin-13, and interleukin-17 (A). $P$ values for data in $\mathbf{D}$ are indicated. 
p52-Tg/p100-1- mice (Figure 7A). TNF $\alpha$ is known to act synergistically with INF- $\gamma$ in activation of macrophages. ${ }^{44}$ Activated macrophages can release cytotoxic mediators including oxygen radicals and nitric oxide and matrix metalloproteinases, resulting in cell death, matrix degradation, and tissue damage. ${ }^{45}$ Moreover, activated macrophages can produce proinflammatory chemokines including CXCL9, CXCL10, CCL2, CCL3, and CCL4, ${ }^{40,44}$ which in turn can amplify the inflammatory response by recruiting additional lymphocytes and monocytes into the site of inflammation, ${ }^{46-49}$ leading to a cycle of inflammatory processes.

The lungs of $\mathrm{p} 52-\mathrm{Tg} / \mathrm{p} 100^{-1-}$ mice also displayed prominent peribronchial fibrosis, most likely as a consequence of the marked accumulation of fibroblasts and myofibroblasts, which are primarily responsible for the production and deposition of collagen. Several cytokines and chemokines with known regulatory functions in fibroblast proliferation and activation were up-regulated in the lungs of $\mathrm{p} 52-\mathrm{Tg} / \mathrm{p} 100^{-1-}$ mice, including TNF $\alpha$, CCR2 and its ligands, and CXCL12. TNF $\alpha$ can promote the proliferation of fibroblasts in vivo and in vitro. ${ }^{50,51}$ Moreover, transgenic mice with targeted expression of TNF $\alpha$ in alveolar type II epithelial cells develop progressive pulmonary fibrosis with fibroblast accumulation. ${ }^{52}$ The myofibroblasts could be derived from resident fibroblasts, mesenchymal progenitor cells, and circulating fibrocytes. ${ }^{33,53,54}$ CCR2 and its ligands have been shown to play an important role in recruiting fibrocytes into the lung, contributing to the pathogenesis of pulmonary fibrosis. ${ }^{55,56}$ Importantly, CCR2 ${ }^{-1-}$ mice are resistant to experimental pulmonary fibrosis induced by bleomycin or fluorescein isothiocyanate. ${ }^{57} \mathrm{CXCL} 12$ is a chemoattractant for circulating fibrocytes. ${ }^{58}$ The TNF $\alpha$, CCR2, and CXCL12 signaling pathways may act synergistically in inducing the accumulation of myofibroblasts and fibrotic lesions in the lungs of $\mathrm{p} 52-\mathrm{Tg} / \mathrm{p} 100^{-1-}$ mice.

In summary, our analysis of the phenotypes of NF- $\kappa \mathrm{B} 2$ p52-Tg mice with or without the NF- $\kappa$ B2 p100 precursor protein provides genetic evidence for a key role of p100 in the control of NF-кB2 signaling. It also illustrates an autoregulatory loop formed between a precursor protein and its processed product for a tight control of signaling output.

\section{Acknowledgment}

We thank Dr. William Gunning (University of Toledo Health Science Campus) for initial histopathology analysis.

\section{References}

1. Claudio E, Brown K, Park S, Wang H, Siebenlist U: BAFF-induced NEMO-independent processing of NF- $\kappa$ B2 in maturing B cells. Nat Immunol 2002, 3:958-965

2. Kayagaki N, Yan M, Seshasayee D, Wang H, Lee W, French DM, Grewal IS, Cochran AG, Gordon NC, Yin J, Starovasnik MA, Dixit VM: BAFF/BLyS receptor 3 binds the B cell survival factor BAFF ligand through a discrete surface loop and promotes processing of NF- $\kappa$ B2. Immunity 2002, 17:515-524
3. Dejardin E, Droin NM, Delhase M, Haas E, Cao Y, Makris C, Li ZW, Karin M, Ware CF, Green DR: The lymphotoxin- $\beta$ receptor induces different patterns of gene expression via two NF- $\kappa$ B pathways. Immunity 2002, 17:525-535

4. Coope HJ, Atkinson PG, Huhse B, Belich M, Janzen J, Holman MJ Klaus GG, Johnston LH, Ley SC: CD40 regulates the processing of NF- $\kappa$ B2 p100 to p52. EMBO J 2002, 21:5375-5385

5. Novack DV, Yin L, Hagen-Stapleton A, Schreiber RD, Goeddel DV, Ross FP, Teitelbaum SL: The $1 \kappa B$ function of NF- $\kappa$ B2 p100 controls stimulated osteoclastogenesis. J Exp Med 2003, 198:771-781

6. Xiao G, Harhaj EW, Sun SC: NF- $\kappa$ B-inducing kinase regulates the processing of NF- $\kappa$ B2 p100. Mol Cell 2001, 7:401-419

7. Senftleben U, Cao Y, Xiao G, Greten FR, Krahn G, Bonizzi G, Chen Y, $\mathrm{Hu} Y$, Fong A, Sun SC, Karin M: Activation by IKK $\alpha$ of a second, evolutionary conserved. NF- $\kappa B$ signaling pathway. Science 2001, 293:1495-1499

8. Beinke S, Ley SC: Functions of NF- $\kappa$ B1 and NF- $\kappa$ B2 in immune cell biology, Biochem J 2004, 382:393-409

9. Gilmore TD: Introduction to NF- $\kappa$ B: players, pathways, perspectives. Oncogene 2006, 25:6680-6684

10. Weih F, Caamano J: Regulation of secondary lymphoid organ development by the nuclear factor- $\kappa \mathrm{B}$ signal transduction pathway. Immunol Rev 2003, 195:91-105

11. Scheinman Rl, Beg AA, Baldwin AS Jr: NF- $k B$ p100 (Lyt-10) is a component of H2TF1 and can function as an I $\kappa$ B-like molecule. Mol Cell Biol 1993, 13:6089-6101

12. Solan NJ, Miyoshi H, Carmona EM, Bren GD, Paya CV: RelB cellular regulation and transcriptional activity are regulated by $\mathrm{p} 100$. J Biol Chem 2002, 277:1405-1418

13. Derudder E, Dejardin E, Pritchard LL, Green DR, Korner M, Baud V: RelB/p50 dimers are differentially regulated by tumor necrosis factor- $\alpha$ and lymphotoxin- $\beta$ receptor activation: critical roles for $\mathrm{p} 100$. J Biol Chem 2003, 278:23278-23284

14. Basak S, Kim H, Kearns JD, Tergaonkar V, O'Dea E, Werner SL, Benedict CA, Ware CF, Ghosh G, Verma IM, Hoffmann A: A fourth I $\mathrm{B}$ protein within the NF- $\kappa$ B signaling module. Cell 2007, 128:369-381

15. Ishikawa H, Carrasco D, Claudio E, Ryseck RP, Bravo R: Gastric hyperplasia and increased proliferative responses of lymphocytes in mice lacking the $\mathrm{COOH}$-terminal ankyrin domain of NF- $\kappa \mathrm{B} 2$. J Exp Med 1997, 186:999-1014

16. Liptay S, Schmid RM, Nabel EG, Nabel GJ: Transcriptional regulation of NF- $\kappa$ B2: evidence for $\kappa \mathrm{B}$-mediated positive and negative autoregulation. Mol Cell Biol 1994, 14:7695-7703

17. Lombardi L, Ciana P, Cappellini C, Trecca D, Guerrini L, Migliazza A, Maiolo AT, Neri A: Structural and functional characterization of the promoter regions of the NFKB2 gene. Nucleic Acids Res 1995, 23:2328-2336

18. Wang Z, Zhang B, Yang L, Ding J, Ding HF: Constitutive production of NF- $\kappa$ B2 p52 is not tumorigenic but predisposes mice to inflammatory autoimmune disease by repressing Bim expression. J Biol Chem 2008, 283:10698-10706

19. Pircher H, Mak TW, Lang R, Ballhausen W, Ruedi E, Hengartner H, Zinkernagel RM, Burki K: T cell tolerance to Mlsa encoded antigens in T cell receptor $\vee \beta 8.1$ chain transgenic mice. EMBO J 1989, 8:719-727

20. Caamaño JH, Rizzo CA, Durham SK, Barton DS, Raventos-Suarez C, Snapper CM, Bravo R: Nuclear factor (NF)-кB2 (p100/p52) is required for normal splenic microarchitecture and B cell-mediated immune responses. J Exp Med 1998, 187:185-196

21. Wang Y, Cui H, Schroering A, Ding JL, Lane WS, McGill G, Fisher DE, Ding HF: NF- $\kappa$ B2 $p 100$ is a pro-apoptotic protein with anti-oncogenic function. Nat Cell Biol 2002, 4:888-893

22. Lernbecher T, Muller U, Wirth T: Distinct NF-kB/Rel transcription factors are responsible for tissue-specific and inducible gene activation. Nature 1993, 365:767-770

23. Finco TS, Beg AA, Baldwin AS Jr: Inducible phosphorylation of $I_{\kappa} B \alpha$ is not sufficient for its dissociation from NF- $\kappa \mathrm{B}$ and is inhibited by protease inhibitors, Proc Natl Acad Sci USA 1994, 91:11884-11888

24. Pelegrí C, Rodriguez-Palmero M, Morante MP, Comas J, Castell M, Franch A: Comparison of four lymphocyte isolation methods applied to rodent T cell subpopulations and B cells. J Immunol Methods 1995, 187:265-271

25. Zhang B, Wang Z, Ding J, Peterson P, Gunning WT, Ding HF: NF-кB2 is required for the control of autoimmunity by regulating the development of medullary thymic epithelial cells. J Biol Chem 2006, 281:38617-38624 
26. Shen ZJ, Esnault S, Rosenthal LA, Szakaly RJ, Sorkness RL, Westmark PR, Sandor M, Malter JS: Pin1 regulates TGF- $\beta 1$ production by activated human and murine eosinophils and contributes to allergic lung fibrosis. J Clin Invest 2008, 118:479-490

27. Fusco AJ, Savinova OV, Talwar R, Kearns JD, Hoffmann A, Ghosh G: Stabilization of RelB requires multidomain interactions with p100/p52. J Biol Chem 2008, 283:12324-12332

28. Reynolds HY: Lung inflammation and fibrosis: an alveolar macrophage-centered perspective from the 1970s to 1980s. Am J Respir Crit Care Med 2005, 171:98-102

29. Leenen PJ, de Bruijn MF, Voerman JS, Campbell PA, van Ewijk W: Markers of mouse macrophage development detected by monoclonal antibodies. J Immunol Methods 1994, 174:5-19

30. Kalluri R, Zeisberg M: Fibroblasts in cancer. Nat Rev Cancer 2006, 6:392-401

31. Lawson WE, Polosukhin VV, Zoia O, Stathopoulos GT, Han W, Plieth D, Loyd JE, Neilson EG, Blackwell TS: Characterization of fibroblastspecific protein 1 in pulmonary fibrosis. Am J Respir Crit Care Med 2005, 171:899-907

32. Tager AM, LaCamera P, Shea BS, Campanella GS, Selman M, Zhao Z, Polosukhin V, Wain J, Karimi-Shah BA, Kim ND, Hart WK, Pardo A Blackwell TS, Xu Y, Chun J, Luster AD: The lysophosphatidic acid receptor LPA1 links pulmonary fibrosis to lung injury by mediating fibroblast recruitment and vascular leak. Nat Med 2008, 14:45-54

33. Phan SH: Biology of fibroblasts and myofibroblasts. Proc Am Thorac Soc 2008, 5:334-337

34. Bhowmick NA, Neilson EG, Moses HL: Stromal fibroblasts in cancer initiation and progression. Nature 2004, 432:332-337

35. Mueller MM, Fusenig NE: Friends or foes-bipolar effects of the tumour stroma in cancer. Nat Rev Cancer 2004, 4:839-849

36. Schroder K, Hertzog PJ, Ravasi T, Hume DA: Interferon- $\gamma$ : an overview of signals, mechanisms and functions. J Leukoc Biol 2004 , 75:163-189

37. Liew FY: $T_{H} 1$ and $T_{H} 2$ cells: a historical perspective. Nat Rev Immunol 2002, 2:55-60

38. Szabo SJ, Sullivan BM, Peng SL, Glimcher LH: Molecular mechanisms regulating Th1 immune responses. Annu Rev Immunol 2003, 21:713-758

39. Dong C: TH17 cells in development: an updated view of their molecular identity and genetic programming. Nat Rev Immunol 2008 8:337-348

40. Mantovani A, Sica A, Sozzani S, Allavena P, Vecchi A, Locati M: The chemokine system in diverse forms of macrophage activation and polarization. Trends Immunol 2004, 25:677-686

41. Chen W, Chatta GS, Rubin WD, Clark JG, Hackman RC, Madtes DK Ligitt DH, Kusunoki Y, Martin PJ, Cheever MA: T cells specific for a polymorphic segment of CD45 induce graft-versus-host disease with predominant pulmonary vasculitis. J Immunol 1998, 161:909-918

42. Clark JG, Madtes DK, Hackman RC, Chen W, Cheever MA, Martin PJ: Lung injury induced by alloreactive Th1 cells is characterized by host-derived mononuclear cell inflammation and activation of alveolar macrophages. J Immunol 1998, 161:1913-1920

43. Renauld JC: Class II cytokine receptors and their ligands: key antivira and inflammatory modulators. Nat Rev Immunol 2003, 3:667-676

44. Mosser DM: The many faces of macrophage activation. J Leukoc Biol 2003, 73:209-212

45. Duffield JS: The inflammatory macrophage: a story of Jekyll and Hyde. Clin Sci (Lond) 2003, 104:27-38

46. Appay V, Rowland-Jones SL: RANTES: a versatile and controversial chemokine. Trends Immunol 2001, 22:83-87

47. Liao F, Rabin RL, Yannelli JR, Koniaris LG, Vanguri P, Farber JM Human Mig chemokine: biochemical and functional characterization. J Exp Med 1995, 182:1301-1314

48. Rollins BJ, Yoshimura T, Leonard EJ, Pober JS: Cytokine-activated human endothelial cells synthesize and secrete a monocyte chemoattractant, MCP-1/JE. Am J Pathol 1990, 136:1229-1233

49. Taub DD, Conlon K, Lloyd AR, Oppenheim JJ, Kelvin DJ: Preferential migration of activated $\mathrm{CD} 4^{+}$and $\mathrm{CD} 8^{+}$T cells in response to MIP- $1 \alpha$ and MIP-1 $\beta$. Science 1993, 260:355-358

50. Piguet PF, Grau GE, Vassalli P: Subcutaneous perfusion of tumor necrosis factor induces local proliferation of fibroblasts, capillaries, and epidermal cells, or massive tissue necrosis. Am J Pathol 1990, 136:103-110

51. Sugarman BJ, Aggarwal BB, Hass PE, Figari IS, Palladino MA Jr Shepard HM: Recombinant human tumor necrosis factor- $\alpha$ : effects on proliferation of normal and transformed cells in vitro. Science 1985 230:943-945

52. Miyazaki Y, Araki K, Vesin C, Garcia I, Kapanci Y, Whitsett JA, Piguet PF, Vassalli $P$ : Expression of a tumor necrosis factor- $\alpha$ transgene in murine lung causes lymphocytic and fibrosing alveolitis. A mouse model of progressive pulmonary fibrosis. J Clin Invest 1995, 96:250-259

53. Hinz B, Phan SH, Thannickal VJ, Galli A, Bochaton-Piallat ML, Gabbian G: The myofibroblast: one function, multiple origins. Am J Pathol 2007, 170:1807-1816

54. Wynn TA: Common and unique mechanisms regulate fibrosis in various fibroproliferative diseases. J Clin Invest 2007, 117:524-529

55. Moore BB, Kolodsick JE, Thannickal VJ, Cooke K, Moore TA, Hogaboam C, Wilke CA, Toews GB: CCR2-mediated recruitment of fibrocytes to the alveolar space after fibrotic injury. Am J Pathol 2005, 166:675-684

56. Moore BB, Murray L, Das A, Wilke CA, Herrygers AB, Toews GB: The role of CCL12 in the recruitment of fibrocytes and lung fibrosis. Am J Respir Cell Mol Biol 2006, 35:175-181

57. Gharaee-Kermani M, McCullumsmith RE, Charo IF, Kunkel SL, Phan $\mathrm{SH}$ : CC-chemokine receptor 2 required for bleomycin-induced pulmonary fibrosis. Cytokine 2003, 24:266-276

58. Phillips RJ, Burdick MD, Hong K, Lutz MA, Murray LA, Xue YY, Belperio JA, Keane MP, Strieter RM: Circulating fibrocytes traffic to the lungs in response to CXCL12 and mediate fibrosis. J Clin Invest 2004, 114:438-446 